\title{
Covid 19: Implication for Insurance, Risk Management and Insurability of Pandemic Risk
}

\author{
SAKA, Toyin Shafau \\ Lecturer, Insurance Department \\ Lagos State Polytechnic, \\ School of Management and Business Studies. \\ E-mail: sakysuccess@yahoo.com
}

Phone: +2348076023583

\begin{abstract}
The incessant fall in the world economy has a result of the COVID-19 epidemic attracted the interest of many researchers. The pandemic brought about a sharp decline in insurance business and economic growth of the nation, this warranted the closure of many businesses and the insurance businesses is not spared. The objective of this paper is to ascertain the effect of Covid 19 on the insurance business and to determine the most efficient risk management strategies that can coup the effect of the Covid 19 pandemic. Both secondary and primary data was used for this study. Regression model was employed to test the hypotheses raised in this paper. This paper revealed that Covid 19 has significant negative effect on the business operation of insurance businesses in Nigeria. Arisen from the analysis of the study, the paper recommended that: insurance industry should employ effective risk management strategy; there is urgent need for insurance industries to re-strategies their business operation by introducing new products and services; and insurance companies should introduce attractive prices through price reduction and engage fully the e-marketing system.
\end{abstract}

Keyword: COVID - 19 pandemics, Insurance, Risk Management, Insurability

Proceedings Reference Format

Saka, T.S. (2021): Covid 19: Implication for Insurance, Risk Management and Insurability of Pandemic Risk. Proceedings of the 27th iSTEAMS Multidisciplinary Innovations \& Technology Transfer (MINTT) Conference. Academic City University College, Accra, Ghana. June, 2021. Pp 255-266 www.isteams.net/ghana2021. DOI - https://doi.org/ 10.22624/AIMS/iSTEAMS-2021/V27P21

\section{INTRODUCTION}

The Corona virus pandemic has drastically affected the economy of the entire world, Nigeria and Lagos state is not spared. The corona virus pandemic significantly affects virtually all phases of business, and this put huge responsibility on the insurance industry. Certain economic variables affected by the Corona Virus pandemic are: Tourism and Agricultural sector, Transportation, Internally Generated Revenue, Financial and Capital Market Institutions, Health Sector, Educational Sectors, Manufacturing, and Small and medium Scale Enterprises. This call for urgent attention of the regulators to conduct extraordinary solvency tests to certify that insurers can survive the instantaneous and severe impacts of the said virus. This unforeseen pandemic has significant implication on the insurance industry, because they became the rescuer of the collapsing business, meanwhile, the insurance industry is also demanding for rescue. 


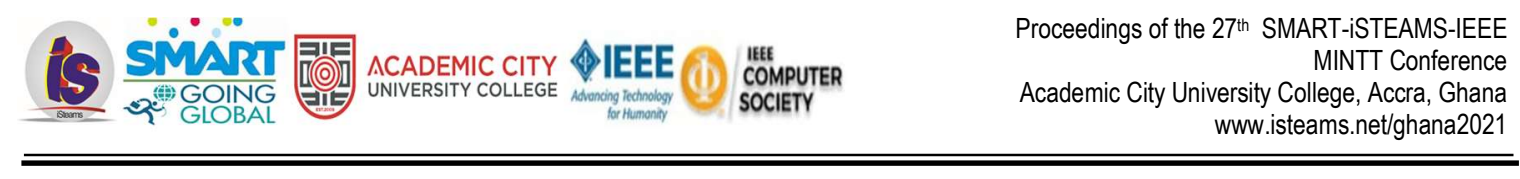

Corona virus evolved from the family of Corona Viridae in the order of Nido Virales. Viruses are microscopic organisms and exist virtually everywhere on earth. Virus can infect plants, animals, fungi, and also human. Occasionally, a virus can result into a disease so deadly and fatal. Although other viral infections generate no obvious reaction (Peter, 2020). The Cluster of cases of pneumonia of unknown cause detected in the city of Wuhan, Hubei Province of China was brought to the notice of World Health Organisation (WHO) on 31 December 2019. The corona virus disease (COVID-19) was identified as the causative virus by Chinese authorities on 7 January. On the 25thof February 2020, Lagos state recorded her index case of Corona Virus. The president of the Federal Republic of Nigeria (Muhammadu Buhari - 2020), declared a total lockdown in Lagos, Abuja and Ogun on 29th March, 2020 for two weeks Nigeria being the Africa's largest economy extended its lockdown by additional two weeks in Lagos, Abuja and Ogun States. The extension came into effect at 11:59 pm on Monday, 13th of April, 2020, as a result, the entire economy of the state partially collapses, this including the Insurance industry.

Despite the measure of temporally lockdown by the government of Nigeria, the spread of the virus kept increasing, the number of confirmed cases as at, May 10 th 2021 stood at 19,147 patients of carrier of the Virus in Nigeria, meanwhile, Lagos state recorded the highest number of cases $(8,177)$, despite the total lockdown and other measures taken to curb the virus. The bid to contain the spread of the corona virus disease has led to downfall of the Insurance industry as customers were not allowed to visit any Insurance and travel restrictions across the globe affects Tourism businesses, with Nigeria also being affected. The lockdown directives given by the government led to the shutdown of many businesses, most especially those that cannot be operate from homes. However, businesses that are offering essential services were exempted from the lockdown directive; hence, the nation's economy is adversely affected. Insurance businesses, Tourism and Aviation as one of the major sources of revenue generation in Lagos State has been one of the hardest-hit sectors, as the lockdown and travel restrictions have caused a huge slump in demand among travellers. Most of the local and foreign airlines have suspended operations, with all the airports under a shutdown order by the Federal Government.

\subsection{Objective of the Study}

The objectives of this paper are to:

1. Determine the effect of Covid-19 on the insurance industry.

2. Ascertain how risk management strategy can coup the effect of the pandemic.

\section{REVIEW OF LITERATURES ON COVID-19}

In 2003, the Chinese populace was tainted with an infection causing Extreme Intense Respiratory Disorder (SARS) in Guangdong territory. The infection was affirmed as a part of the Beta- coronavirus subgroup and was named SARS-CoV (Peiris, Guan, \& Yuen, 2004). The contaminated patients displayed pneumonia indications with a diffused alveolar harm which is driven to intense respiratory trouble disorder (ARDS). SARS at first risen in Guangdong, China, and after that spread quickly around the globe with more than 8000 tainted people and 776 deceased. A decade afterwards in 2012, some Saudi Middle eastern nationals were analysed to be contaminated with another coronavirus. The recognized infection was affirmed as a part of coronaviruses and named the Centre East Respiratory Disorder Coronavirus (MERS-CoV). The World wellbeing organization detailed that MERS- coronavirus infected more than 2428 people and 838 deaths (Rahman \& Sarkar, 2019). MERS-CoV could be a part beta-corona infection subgroup and phylogenetically assorted from other humanCoV. 


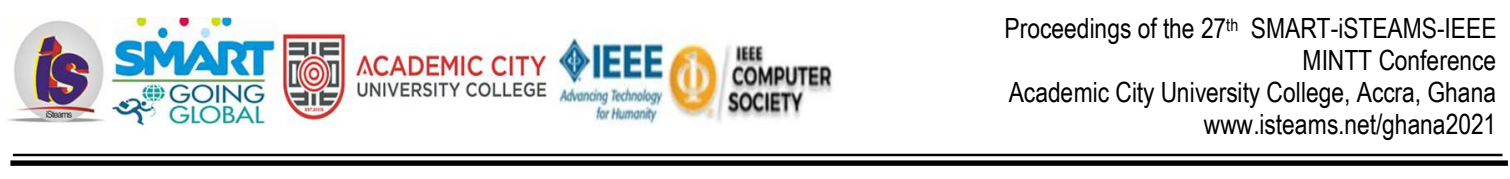

The disease of MERS- CoV starts from a gentle upper respiratory harm whereas movement leads to serious respiratory infection. Comparable to SARS coronavirus, patients contaminated with MERS-corona infection endure pneumonia, taken after by ARDS and renal disappointment (Memish, Zumla, Al-Hakeem, Al-Rabeeah, \& Stephens, 2013). Recently, by the conclusion of 2019, WHO was educated by the Chinese government approximately a few cases of pneumonia. The flare-up was started from the Hunan fish advertisement in Wuhan city of China and quickly tainted more than 50 individuals. The live creatures are habitually sold at the Hunan fish showcase such as bats, frogs, snakes, feathered creatures, marmots, and rabbits (Wang, Horby, Hayden, \& Gao, 2020). On 12 January 2020, the National Wellbeing Commission of China discharged encourage subtle elements around the plague, recommended viral pneumonia (Wang, Horby, Hayden, \& Gao, 2020).

From the sequence-based investigation of confines from the patients, the infection was distinguished as a novel coronavirus. In addition, the hereditary grouping was too given for the conclusion of viral disease. At first, it was proposed that the patients contaminated with Wuhan crown virus-induced pneumonia in China may have gone by the fish advertise where live creatures were sold or may have utilized contaminated creatures or fowls as a source of nourishment. These perceptions demonstrated a human to the human spreading capability of this infection, which was in this way detailed in more than 100 nations within the world. The human to the human spreading of the virus happens due to shut contact with a contaminated individual, uncovered to hacking, sniffling, respiratory beads, or mist concentrates. These pressurized canned products can enter the human body (lungs) through inward breath through the nose or mouth.

The source of beginning and transmission is critical to be decided to create preventive methodologies to contain the contamination. Within the case of SARS-CoV, the analysts at first centred on raccoon mutts and palm civets as a key supply of disease. In any case, as it were the tests disconnected from the civets at the nourishment showcase appeared positive comes about for viral RNA discovery, recommending that the civet palm may well be auxiliary has (Kan, et al., 2005). In 2001 the tests were disconnected from the solid people of Hongkong and the atomic evaluation appeared a 2.5\%frequency rate of anti-bodies against the SARS-corona infection. These signs recommended that the SARS-corona infection may be circulating in people some time recently causing the flare-up in 2003 (Zheng, et al., 2004). Afterwards on, Rhinolophus bats were moreover found to have anti-SARS-CoV antibodies proposing the bats as a source of viral replication (Shi \& Hu, 2008). The Center East respiratory disorder (MERS) coronavirus to begin with risen in 2012 in Saudi Arabia (Memish, Zumla, AlHakeem, Al-Rabeeah, \& Stephens, 2013).

All coronaviruses contain particular qualities in ORF1 downstream locales that encode proteins for viral replication, nucleocapsid, and spikes arrangement (Van, et al., 2012). The glycoprotein spikes on the external surface of coronaviruses are mindful of the connection and section of the infection to have cells. Their receptorbinding space (RBD) is freely joined among infections; hence, the infection may contaminate different has (Raj VS, 2013). Other coronaviruses generally recognize aminopeptidases or carbohydrates as a key receptor for a section to human cells whereas SARS-CoV and MERS-CoV recognize exopeptidases (Wang, et al., 2013). The passage component of a coronavirus depends upon cellular proteases which incorporate, human aviation route trypsin-like protease (Cap), cathepsins, and transmembrane protease serine 2 (TMPRSS2) that part the spike protein and set up advance infiltration changes (Bertram, et al., 2011). MERS-coronavirus utilizes dipeptidyl peptidase4(DPP4), whereas HCV-NL63andSARS-coronavirus require protein conjointly communicated other polyproteins, nucleoproteins, and film proteins, such as RNA polymerase, 3chymotrypsin-like protease, papain-like protease, helicase, glycoprotein, and embellishment proteins (Wu, et al., 2020). 


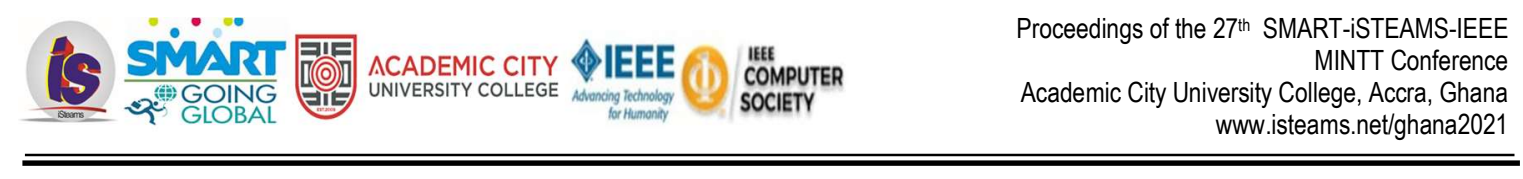

The spike protein of SARS-CoV-2 contains a 3-D structure within the RBD locale to preserve the van der Waals strengths (Xu, et al., 2020). The 394-glutamine build-up within the RBD locale of SARS-CoV-2 is recognized by the basic lysine 31 build-up on the human ACE2 receptor (Faded, Shang, Graham, Baric, \& Li, 2020). The whole instrument of pathogenicity of SARS-CoV-2.

\subsection{Coronavirus in Nigeria}

The Federal Ministry of Health affirmed a coronavirus disease (COVID-19) case in Lagos State, Nigeria. The case, which was affirmed on the 27th of February 2020, is the primary case to be detailed in Nigeria since the starting of the episode in China in January 2020. The case is an Italian citizen who works in Nigeria and returned from Milan, Italy to Lagos, Nigeria on the 25th of February 2020. He was affirmed by the Virology Research facility of the Lagos College Instructing Healing centre, a portion of the Research facility Arrange of the Nigeria Middle for Illness Control. The quiet is clinically steady, with no genuine side effects, and is being overseen at the Irresistible Malady Healing centre in Yaba, Lagos.

The Government of Nigeria, through the Government Service of Wellbeing, has been reinforcing measures to guarantee an episode in Nigeria is controlled and contained rapidly. The multi-sectoral Coronavirus Readiness Bunch driven by the Nigeria Middle for Malady Control (NCDC) has instantly enacted its National Crisis Operations Middle and will work closely with Lagos State Wellbeing specialists to reply to this case and execute firm control measures. As of the time of witting this paper, add up to 162,891 affirmed cases of the infection as recorded with Lagos state being the lead with 58,367.

\subsection{Insurability of Pandemic Risk}

The effect of COVID-19 on worldwide protections markets is to a great extent felt through resource dangers, eminently capital markets instability, and weaker premium development prospects. S\&P Worldwide Evaluations anticipate most COVID-19 related misfortunes (commerce interference, occasion cancellation, etc.) to be picked up by reinsurers, so essential insurers' specialized execution is impossible to break down substantially. Strict lockdown measures made a difference keep up palatable execution, as engine and restorative claims had a positive effect on misfortune proportions (Bertram, et al., 2011). Created markets, especially life ones, are likely to recoil in genuine terms as a result of the financial slowdown. Developing markets, through their less secure resource allotment, will likely encounter more decreases in return on value than created markets. Ultralow intrigued rates cruel that the foremost critical source of hazard to safeguards is the execution of speculations, particularly life guarantees with ensured back books (Osagie, 2020).

It is apparent to note that not all risks can be insured especially risks that cannot be calculated (Shi \& Hu, 2008). However, all risks still needed to be insured. Insurers are now put on their toes to put in their professional expertise in place to ensure that uncalculated risk are insurable (Abdur, 2020). This first report in our research series on pandemics and insurance explores, in number terms, the capacities of insurers to absorb pandemicrelated costs. Encouragingly, research findings indicate that pandemics on the scale of, and similarly lethal to, COVID-19 pose no fundamental insurability challenges for health and life insurers. In the commercial insurance arena, however, the uncontrollable aggregation and correlation elements of pandemic risk defy insurability. According to Abdur (2020), the capacities of insurance to retain pandemic-related costs. Enthusiastically, inquire about discoveries demonstrate that pandemics on the scale of, and essentially deadly to, COVID-19 posture no crucial insurability challenges for wellbeing and life safeguards. Within the commercial protections field, be that as it may, the wild accumulation and relationship components of widespread chance oppose insurability.

\subsection{Risk Management Strategies}




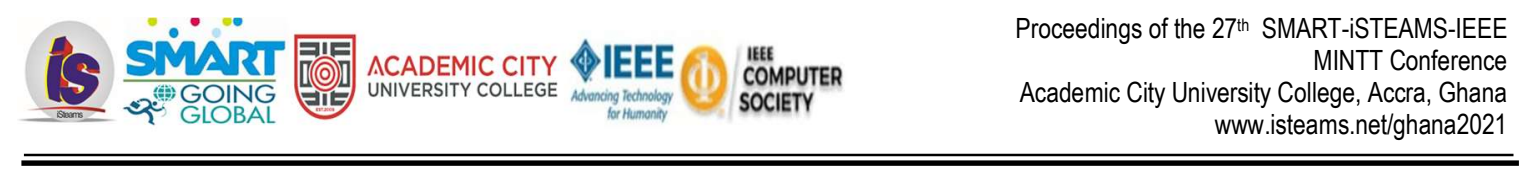

The basic methods forrisk management-avoidance, retention, sharing, transferring, and loss prevention and reduction - can apply to all facets of an individual's life and can pay off in the long run. In this paper, these five methods and how they can apply to the management of health risks are reviewed.

\section{Avoidance}

Avoidance is a method for mitigating risk by not participating in activities that may incur injury, sickness, or death. Smoking cigarettes is an example of one such activity because avoiding it may lessen both health and financial risks. Life insurance companies mitigate this risk on their end by raising premiums for smokers versus non-smokers. Under theAffordable Health Care Act, also known as Obamacare, health insurers are able to increase premiums based on age, geography, family size, and smoking status. The law allows for up to a $50 \%$ surcharge on premiums for smokers. Risk management strategies used in the financial world can also be applied to managing one's own health (Peter, 2020).

\section{Retention}

Retention is the acknowledgment andacceptance of a risk as given. Usually, this accepted risk is a cost to help offset larger risks down the road, such as opting to select a lower premium health insurance plan that carries a higher deductible rate. The initial risk is the cost of having to pay more out-of-pocket medical expenses if health issues arise. If the issue becomes more serious or life-threatening, then the health insurance benefits are available to cover most of the costs beyond the deductible. If the individual has no serious health issues warranting any additional medical expenses for the year, then they avoidthe out-of-pocket payments, mitigating the larger risk altogether (Lu, et al., 2020).

\section{Sharing}

Sharing risk is often implemented through employer-based benefits that allow the company to pay a portion of insurance premiums with the employee.In essence, this shares the risk with the company and all employees participating in the insurance benefits. The understanding is that with more participants sharing the risks, the costs of premiums should shrink proportionately. Individuals may find it in their best interest to participate in sharing the risk by choosing employer health care and life insurance plans when possible (Kan, et al., 2005).

\section{Transferring}

The use of health insurance is an example of transferring risk because the financial risks associated with health care are transferred from the individual to the insurer. Insurance companies assume the financial risk in exchange for a fee known as a premium and a documented contract between the insurer and individual. The contract states all the stipulations and conditions that must be met and maintained for the insurer to take on the financial responsibility of covering the risk (Raj VS, 2013).

By accepting the terms and conditions and paying the premiums, an individual has managed to transfer most, if not all, the risk to the insurer. The insurer carefully applies many statistics andalgorithmsto accurately determine the proper premium payments commensurate to the requested coverage. When claims are made, the insurer confirms whether the conditions are met to provide the contractual payout for the risk outcome (Rahman \& Sarkar, 2019).

\section{Loss Prevention and Reduction}

This method of risk management attempts to minimize the loss, rather than completely eliminate it. While accepting the risk, it stays focused on keeping the loss contained and preventing it from spreading. An example 
of this in health insurance is preventative care (Wu, et al., 2020). Health insurers encourage preventative care visits, often free of co-pays, where members can receive annual check-ups and physical examinations. Insurers understand that spotting potential health issues early on and administering preventative care can help minimize medical costs in the long run. Many health plans also provide discounts to gyms and health clubs as another means of prevention and reduction in order to keep members active and healthy (Wroblewski, 2019).

\section{METHODOLOGY}

Systematic Review and Meta-Analysis was combined with an exploratory research design approach adopted by the researcher. Both secondary and primary data was employed for this study. Both Primary and Secondary data were used for this study. Data relating to Covid 19 were retrieved from the official website of NCDC and data relating to the performance index of the insurance industry was retrieved from the annual reports of the selected five (5) insurance companies. The study is conducted in Lagos state. There are big insurances of different classes within the Lagos metropolis, some of the popular ones are: Leadway Assurance Company Itd; Sterling Assurance Nigeria Itd; Linkage Assurance PLC; Custodian Life Assurance Ltd; and Coronation Insurance Plc. The population for this study consisted of senior staff of the top five (5) top insurance companies with 152 senior/management staff strength. The commonly used approach for sample size determination is Taro Yamene (1970) formular for sample size determination.

Using the forular, the sample size therefore is;

$s s=\frac{N}{1+N e^{2}}$

Where:

ss $=$ Sample Size

$N=$ Population

$\mathrm{e}=$ error term $(0.05)$

ss $=\frac{152}{1+152(0.05)^{2}}$

ss $=110$ (Insurances Staff).

A total number of One Hundred and Ten (110) copies of questionnaire was administered to the senior staff of the Insurance companies.

\subsection{Reliability of the Research Instruments}

The data collected for this study was coded and enter into SPSS 25.0 and was subjected to a reliability test. The reliability test result is show in the table 1. 


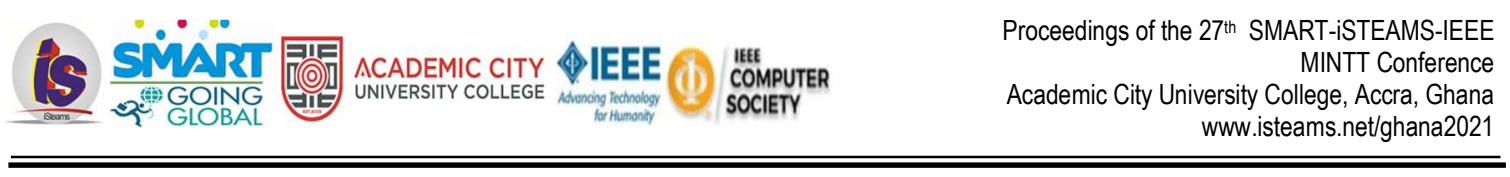

Table 1: Reliability Test Result

Reliability Statistics

\begin{tabular}{|l|l|}
\hline Cronbach's Alpha & N of Items \\
\hline .721 & 76 \\
\hline
\end{tabular}

Source: SPSS 25.0 OUTPUT

The result of the reliability test in table 3 shows that Cronbach Alpha for all the items in the questionnaire is reliable. This means that the questionnaire is reliable enough for further research.

Table 2: Kaiser-Meyer-Olkin (KMO) and Barlett's test of Sphericity KMO and Bartlett's Test

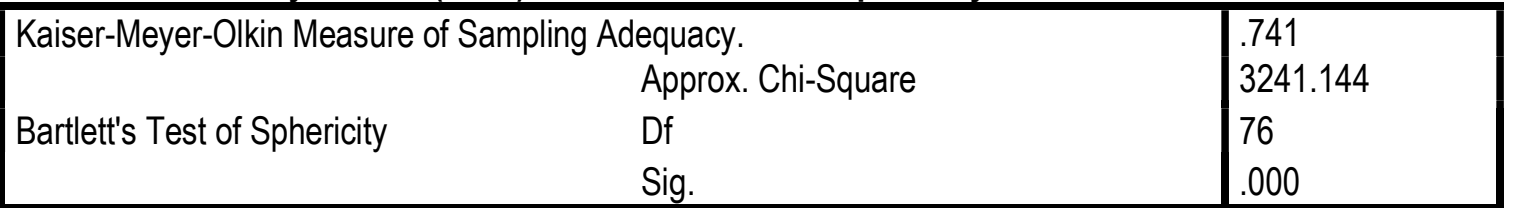

\section{Source: SPSS 25.0 output}

This study conducted the KMO and Barlett's test of Sphericity. The KMO measures the sampling adequacy (which determines if the responses given with the sample are adequate or not) which should be close than 0.5 for a satisfactory factor analysis to proceed. Kaiser (1974) recommend 0.5 (value for KMO) as minimum (barely accepted), values between 0.7-0.8 acceptable, and values above 0.9 are superb. The table 4 shows that the value of $\mathrm{KMO}$ measure for the questionnaire is .670 which is greater than 0.5 and therefore accepted that the sample was adequate.

Bartlett's test is another indication of the strength of the relationship among variables. This tests the null hypothesis that the correlation matrix is an identity matrix. An identity matrix is matrix in which all of the diagonal elements are 1 and all off diagonal elements (term explained above) are close to 0 . From table 2, the Bartlett's Test of Sphericity is significant (0.001). That is, significance is less than 0.05 . This means that correlation matrix is not an identity matrix.

\subsection{Method of Data Analysis}

A total number of 110 questionnaire were administered, however, 76 was well filled and returned. Ordinary Least Square (OLS) regression model was employed to test the hypothesis one and graphical presentation was used to rate the different marketing strategies. (OLS) model is considered appropriate because it has the ability to predict the effect of independent variables on the dependent variables.

\subsection{Formula for Ordinary Least Square model:}

InsPerf $=\alpha+\beta($ Cov-19) + e.

Where:

InsPerf = Insurance Business 
Cov-19 C. $=$ Covid -19 Confirmed cases

$a=$ Intercept

$\beta=$ Slope

$\mathrm{e}=$ Error terms

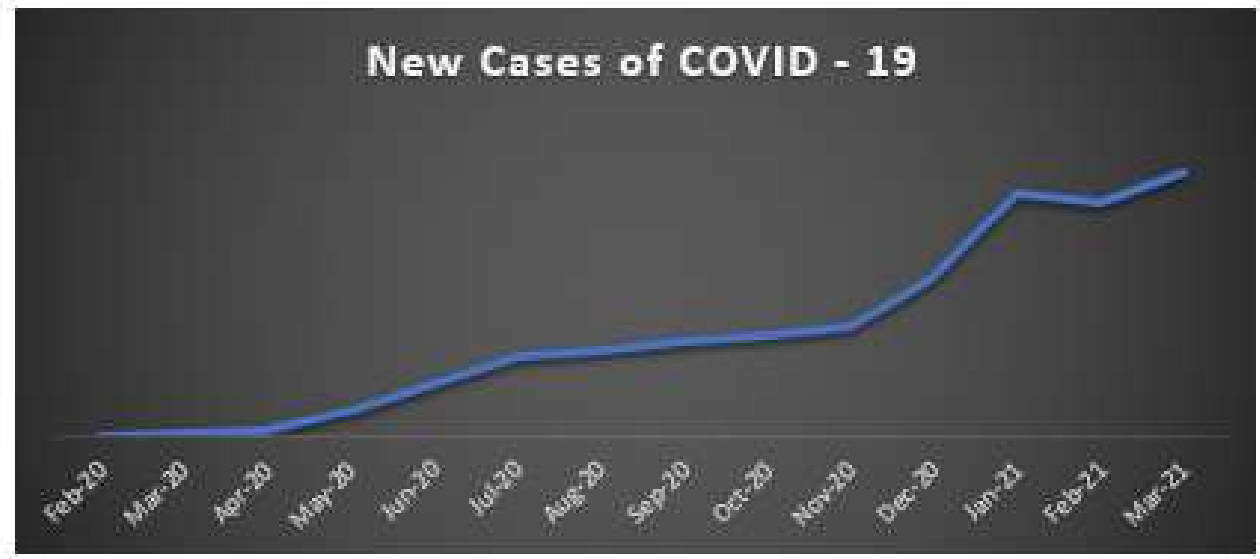

Figure 1: New cases of COVID 19

Source: Researcher's Fieldwork

Figure 1 shows that there is continuous increase in the reported cases of Corona Virus in Nigeria

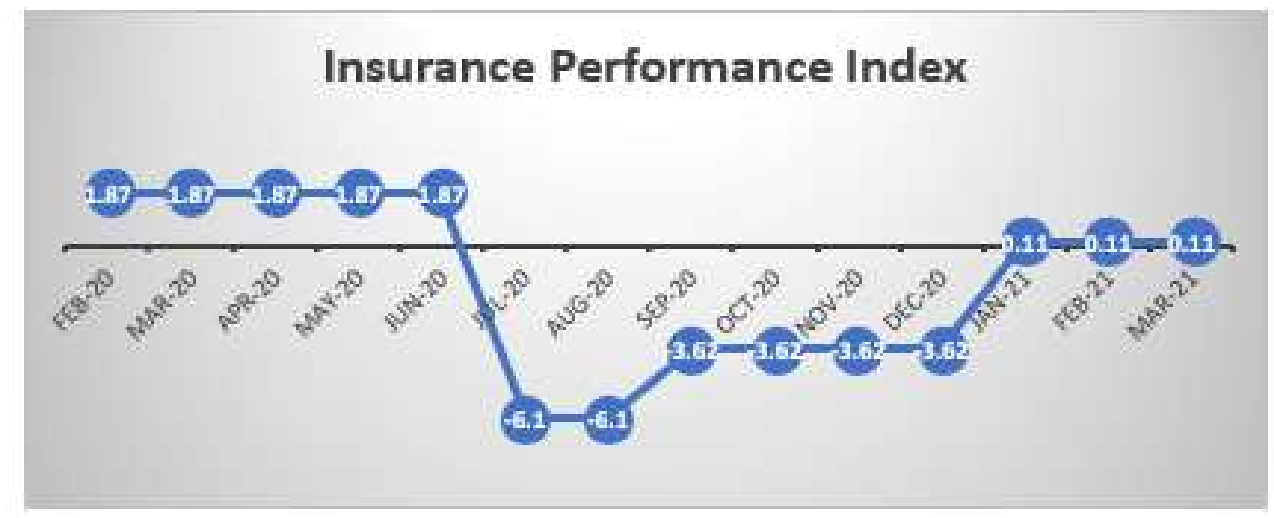

Fig 2: Key Performance Index for Insurplus Industry

Source: Insurance Broker Finds insightsoftware the Ideal Self-Service Financial

Reporting Solution for Oracle ERP Cloud

Figure 2 shows that the was a sharp decline in the Key Performance Index in the Nigeria economy in July 2020, resulting from the impact of the pandemic when all business activities were suspended. 


\section{Hypothesis One}

\section{$\mathrm{H}_{01}$ Covid-19 does not have significant effect on the Performance of Insurance Industry.}

\section{Model Summary}

\begin{tabular}{|l|l|l|l|l|}
\hline Model & R & R Square & Adjusted R Square & Std. Error of the Estimate \\
\hline 1 & $.786^{\mathrm{a}}$ & .735 & -.146 & .15463 \\
\hline
\end{tabular}

a. Predictors: (Constant), Covid - 19

As shown in the model summary result, the relationship (R-Square) between the dependent and independent variables is about $74 \%$, this implies that the independent variable (Covid - 19) can predict or determine dependent variable insurance performance index up to $74 \%$ only.

\section{Coefficients $^{\mathrm{a}}$}

\begin{tabular}{|c|c|c|c|c|c|c|}
\hline \multirow[b]{2}{*}{ Model } & & \multicolumn{2}{|c|}{ Unstandardized Coefficients } & \multirow{2}{*}{\begin{tabular}{|l} 
Standardized \\
Coefficients \\
Beta \\
\end{tabular}} & \multirow[b]{2}{*}{$t$} & \multirow[b]{2}{*}{ Sig. } \\
\hline & & $\mathrm{B}$ & Std. Error & & & \\
\hline & $\begin{array}{l}\text { (Constant) } \\
\text { Covid - } 19\end{array}$ & $\begin{array}{l}-1.554 \\
-2.9505\end{array}$ & $\begin{array}{l}1.312 \\
.012\end{array}$ & -1.186 & $\begin{array}{l}-2.422 \\
-2.657\end{array}$ & $\begin{array}{l}.000 \\
.004\end{array}$ \\
\hline
\end{tabular}

a. Dependent Variable: Key Performance Index

The value of the intercept -1.554 is the predicted value of Performance of Insurance Industry if the independent variable (Covid-19) is equal to zero. Covid - 19 has a coefficient value of $\beta_{1}=-2.950$, t-test $=-2.657, p=.004$, this revealed that a negative significant relationship exists between the performance of insurance industry and Covid-19 epidemic. This means that a unit increase in Covid - 19 account for about -2.950 unit decrease in the performance of insurance industry. 


\section{How Risk Management Strategies Can Coup the Effect of the Pandemic}

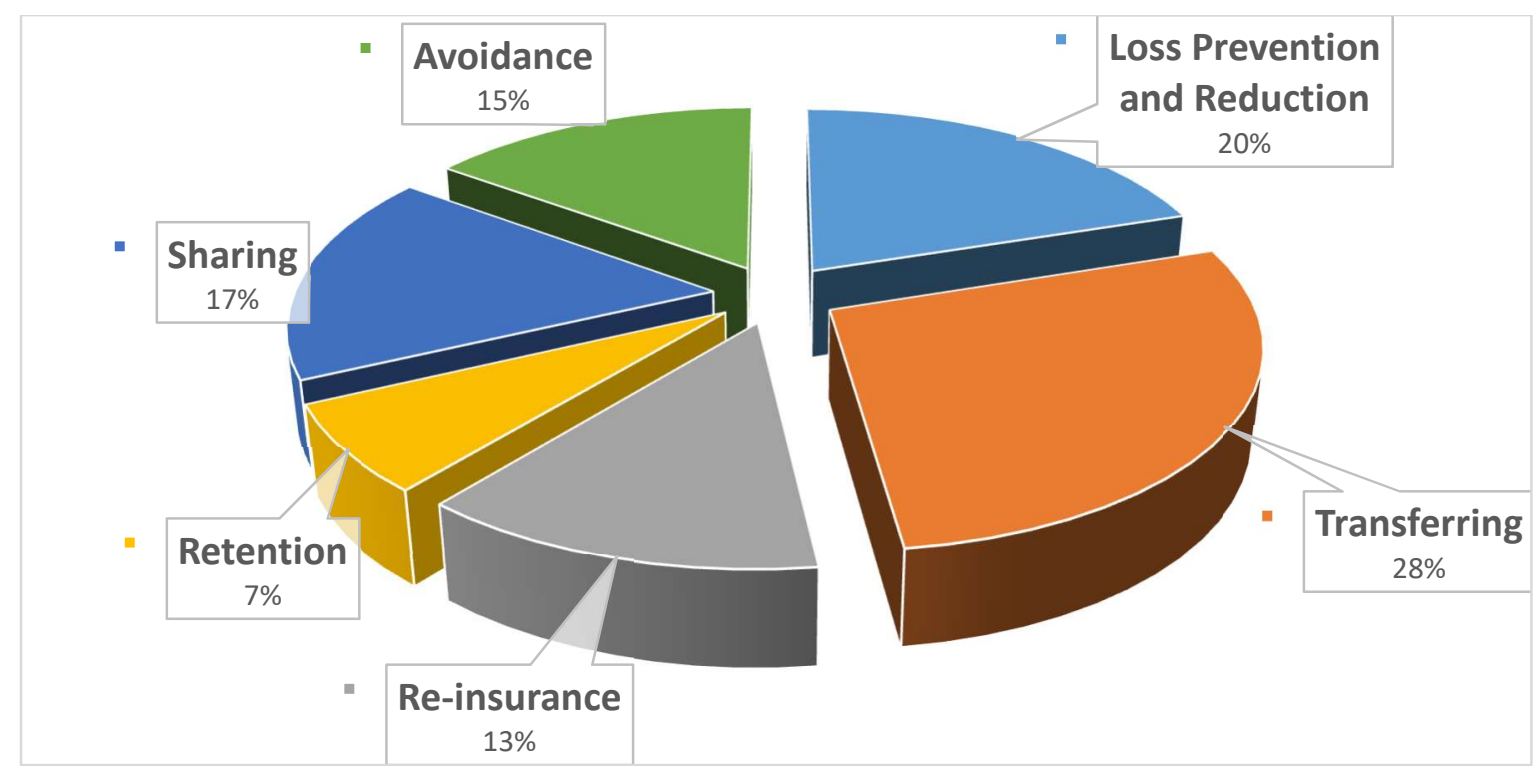

Figure 3: Risk Management Strategic

Source: Excel 2016.

Figure 3 shows that $20 \%$ of the respondents agrees that loss prevention and reduction be consider as a risk management strategy to coup the negative impact of Covid 19 on insurances business. Meanwhile, $15 \%$ of the respondents agrees that the avoidance as a risk management strategy will go a long way to recoup the negative impact of Covid 19 on insurances business, $28 \%$ of the respondents agrees that by risk transfer as a risk management strategy will reduced the negative impact of Covid 19 on insurances business. In the same light, $13 \%$ of the respondents also agree that insurance companies should consider re-insurance as a risk management strategy to coup the negative impact of Covid 19 on insurances business. Just $7 \%$ of the respondents agrees that insurance companies should consider risk retention as a risk management strategy to coup the negative impact of Covid 19 on insurances business. Also, 17\% of the respondents agree to that insurance companies should consider risk sharing as a risk management strategy to coup the negative impact of Covid 19 on insurances business.

\section{CONCLUSION}

The lockdown has a result of COVID-19 pandemic drastically affected the economy of many nation and in extension, the Nigerian economy crumbled into recession as a result. This paper concluded that Covid 19 has significant negative effect on the business operation of insurance businesses in Nigeria, and to ensure that performance of insurance industry is re-guaranteed, there is urgent need for effective risk management strategy.

\section{RECOMMENDATIONS}




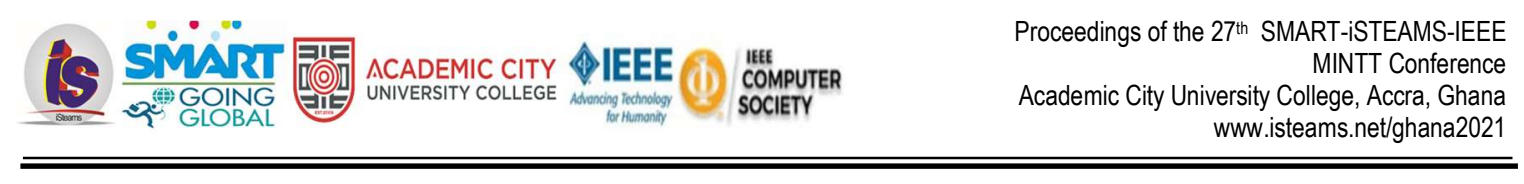

Arisen from the analysis of the study, the paper recommended that:

1. Insurance industry should employ effective risk management strategy.

2. There is urgent need for insurance industries to re-strategies their business operation by introducing new products and services,

3. Insurance companies should introduce attractive prices through price reduction and engage fully the e-marketing system.

\section{REFERENCES}

Abdur, R. A. (2020, April 11). Coronavirus: Buhari meets VP, Task Force; speaker warns Chinese envoy. Retrieved from Africanews: https://www.africanews.com/2020/04/11/nigeria-confirms-thirdcoronavirus-case-index-patient-fully-recovers/

Annan A, B. H. (2013). Human betacoronavirus 2c EMC/2012-related viruses in bats, Ghana and Europe. Emerg Infect Dis, 19(3), 456.

Bertram, S, Glowacka, I., Müller, M., Lavender, H., Gnirss, K., \& Nehlmeier, I. (2011). Cleavage and activation of the severe acute respiratory syndrome coronavirus spike protein by human airway trypsin-like protease. J Virol, 85(24), 13363 - 13372.

Corman, V., Ithete, N., Richards, L., Schoeman, M., Preiser, W., \& Drosten, C. (2014). Rooting the phylogenetic tree of middle East respiratory syndrome coronavirus by characterization of a conspecific virus from an African bat. J Virol, 88(19), 11297 - 11303.

Huynh, J., Li, S., Yount, B., Smith, A., Sturges, L., \& Olsen, J. (2012). Evidence supporting a zoonotic origin of human coronavirus strain NL63. J Virol, 86(23), 1281612825.

Indian-Express. (2014, June 15). Social networking sites to promote goods soon. Retrieved from Indian Express: www.indianexpress.com

Kan, B., Wang, M., Jing, H., Xu, H., Jiang, X., \& Yan, M. (2005). Molecular evolution analysis and geographic investigation of severe acute respiratory syndrome coronavirus-like virus in palm civets at an animal market and on farms. J Virol, 79(18), 11892 - 11900.

Li, B., Si, H.-R., Zhu, Y., Yang, X.-L., Anderson, D., \& Shi, Z.-L. (2020). Discovery of Bat Coronaviruses through Surveillance and Probe Capture-Based Next- Generation Sequencing. mSphere, 5(1).

Lu, R., Zhao, X., Li, J., Niu, P., Yang, B., \& Wu, H. (2020). Genomic characterisation and epidemiology of 2019 novel coronavirus: implications for virus origins and receptor binding. The Lancet.

Memish, Z., Zumla, A., Al-Hakeem, R., Al-Rabeeah, A., \& Stephens, G. (2013). Family cluster of Middle East respiratory syndrome coronavirus infections. N Engl J Med, 368(26), 2487 - 2494.

NCDC. (2020, April 13). COVID - 19 Case Update. Retrieved from 20 New Cases Confirmed: https://en.as.com/en/2020/04/13/other_sports/1586778385_605014.html

Osagie, E. (2020, February 28). First Case Of Corona Virus Disease Confirmed In Nigeria. Retrieved from NCDC: https://ncdc.gov.ng/news/227/first-case-of-corona-virus-disease-confirmed-in-nigeria

Paden, C., Yusof, M., Al-Hammadi, Z., Queen, K., Tao, Y., \& Eltahir, Y. (2018). Zoonotic origin and transmission of Middle East respiratory syndrome coronavirus in the UAE. Zoonoses Public Health, 65(3), 322 333.

Peiris, J., Guan, Y., \& Yuen, K. (2004). Severe acute respiratory syndrome. Nat Med, 10(12), 88 - 97.

Peter, C. (2020, April 08). COVID-19: Latest news and resources. Retrieved from MedicalNewsToday: https://www.medicalnewstoday.com/articles/158179 
Rahman, A., \& Sarkar, A. (2019). Risk factors for fatal middle east respiratory syndrome coronavirus infections in Saudi Arabia: analysis of the WHO Line List. Am J Public Health, 109(9), 1288 - 1293.

Raj VS, M. H. (2013). Dipeptidyl peptidase 4 is a functional receptor for the emerging human coronavirus-EMC. Nature, 495(7440), 251 - 254.

Shi, Z., \& Hu, Z. (2008). A review of studies on animal reservoirs of the SARS coronavirus. Virus Res, 133(1), $74-87$.

Van, B. S., de-Graaf, M., Lauber, C., Bestebroer, T., Raj, V., \& Zaki, A. (2012). Genomic characterization of a newly discovered coronavirus associated with acute respiratory distress syndrome in humans. MBio, 3(6), 00473512.

Wan, Y., Shang, J., Graham, R., Baric, R., \& Li, F. (2020). Receptor recognition by novel coronavirus from Wuhan: an analysis based on decade-long structural studies of SARS. J Virol.

Wang, C., Horby, P., Hayden, F., \& Gao, G. (2020). A novel coronavirus outbreak of global health concern. The Lancet.

Wang, N., Shi, X., Jiang, L., Zhang, S., Wang, D., \& Tong, P. (2013). Structure of MERS-CoV spike receptorbinding domain complexed with human receptor DPP4. Cell Res, 23(8), 986.

Wroblewski, M. (2019, March 18). What are the six major modes of communication marketing. Retrieved from Bussinesses in the World: https// smallbusiness.chron.com

Wu, A., Peng, Y., Huang, B., Ding, X., Wang, X., \& Niu, P. (2020). Genome composition and divergence of the novel coronavirus (2019-nCoV) originating in China. Cell Host Microbe.

Wu, F., Zhao, S., Yu, B., Chen, Y.-M., Wang, W., \& Song, Z.-G. (2020). A new coronavirus associated with human respiratory disease in China. Nature, 1(1), 1 - 5.

Xu, X., Chen, P., Wang, J., Feng, J., Zhou, H., \& Li, X. (2020). Evolution of the novel coronavirus from the ongoing Wuhan outbreak and modeling of its spike protein for risk of human transmission. Science China Life Sciences, 63(3), 457 - 460.

Zheng, B., Guan, Y., Wong, K., Zhou, J., Wong, K., \& Young, B. (2004). SARS-related virus predating SARS outbreak, Hong Kong. Emerg Infect Dis, 10(2), 176. 